\title{
PROTECTION OF RIPARIAN FORESTS AND WATER QUALITY IN A BASIN IN THE ATLANTIC FOREST BIOME
}

\author{
Elenice Fritzsons ${ }^{1 *}$, Luiz Eduardo Mantovani ${ }^{2}$ \\ ${ }^{1 *}$ Embrapa Florestas, Colombo, Paraná, Brazil, elenice.fritzsons@embrapa.br \\ ${ }^{2}$ Federal University of Paraná, Geology Department, Curitiba, Paraná, Brazil, lem@ufpr.br \\ Received for publication: 22/11/2018 - accepted for publication: 08/10/2020
}

\begin{abstract}
Resumo
A proteção das florestas ciliares e qualidade das águas numa bacia no bioma Mata Atlântica. A qualidade da água de uma bacia hidrográfica depende do material de origem da região, do uso das terras e da presença das florestas ciliares, que atuam como filtro, protegendo as águas. Para dimensionar a importância da floresta ciliar e do uso da terra sobre a qualidade de água, foram monitorados os parâmetros de qualidade de água (turbidez, cor, $\mathrm{pH}$, condutividade, sólidos dissolvidos, alcalinidade, nitrato e cloreto) em seis microbacias contíguas durante 3 anos. A região estudada pertence ao bioma Mata Atlântica, com clima úmido subtropical de altitude, ecossistema da Floresta Ombrófila Mista. Foi feita a carta de uso da terra das bacias e, a partir dela, foi obtido o mapa de conflito de uso nas APPs fluviais, que são áreas de preservação permanentes. As principais tipologias de uso da terra encontradas foram: floresta natural, silvicultura, edificações, agricultura e pastagem. Os parâmetros de qualidade de água, os conflitos de uso das APPs e os usos da terra nas bacias hidrográficas foram incluídos nas análises de correlação múltipla. Há conformidade com a legislação das APPs fluviais em $51 \%$ da bacia enquanto em $49 \%$, há conflito com outros usos, ou seja, não há floresta ciliar. A qualidade das águas se alterou ao longo das estações do ano e quando houve conflitos das APPs fluviais com a agricultura, edificação e pastagem. Não houve influência dos diferentes usos da terra nas bacias, sobre os parâmetros de qualidade de água e o mesmo ocorreu com a precipitação sobre a qualidade de água.

Palavras chave: uso da terra, área de preservação permanente, rio, floresta ombrófila mista.
\end{abstract}

\begin{abstract}
The water quality of a drainage basin depends on the vegetation and soil of the region, land use and riparian forests, which act as a filter to protect the watercourse. For three years, we monitored several water quality parameters (turbidity, color, $\mathrm{pH}$, conductivity, dissolved solids, alkalinity, and nitrate and chloride concentrations) in six adjacent microbasins to assess how riparian forests and land use affect water quality. The location is part of the Atlantic forest biome, with high-altitude humid subtropical climate and mixed ombrophilous forests. We designed a land use charter of the basin and a conflict map for fluvial permanent preservation areas. Land use included mainly natural forests, forestry, buildings, agriculture, and pastures. The multiple correlation analyses included: the water quality parameters, conflicts with permanent preservation areas, and land uses in river basins. In $51 \%$ of the basin, land uses complied with fluvial PPA legislation, but in $49 \%$ we found conflicts with other land use typologies and a lack of riparian forests. The quality of the water changed throughout the seasons and when fluvial PPAs conflicted with agriculture, buildings, and pastures. The different land uses in the basins did not influence the parameters of water quality and the same occurred with precipitation on water quality.

Keywords: land use, permanent preservation area, river, mixed ombrophilous rainforest.
\end{abstract}

\section{INTRODUCTION}

Riparian forests, also known as ciliary forests or riparian woodland, are primary or secondary formations that occupy the banks of rivers, streams, and marginal dikes. Riparian forests can improve water infiltration into the soil, maintain the quality of the water, provide shading, stabilize the temperature of the water, minimize bank erosion processes, and supply shelter and food for much of the aquatic fauna (FRITZSONS et al., 2011), working as an ecological corridor for animals and plants. The absence of riparian forests may change water quality, causing an increase the concentration of nutrients and particulate matter, both organic and inorganic, in suspension; changing the temperature of the water; and altering the type and quantity of sediments transported in the basin to aquatic systems. These changes can affect the structure and functions of fluvio-lacustrine ecosystems. Water quality degradation also has severe economic consequences, both direct - in the form of an increase in water treatment costs - and indirect — increased flooding, especially downstream, and headward erosion.

Riparian forests are protected by Law no. 12.651/2012 of the Brazilian Forest Code (BRAZIL, 2012), which considers them a permanent preservation area (PPA). The functions of PPAs, whether native vegetation or not, are to preserve water resources, the landscape, the soil, geological stability, and biodiversity; facilitate the

FLORESTA, Curitiba, PR, v. 51, n. 2, p. 283-292, abril/jun 2021.

Fritzsons, E. et.al.

ISSN eletrônico 1982-4688

DOI: $10.5380 /$ rf.v51 i2. 62957 
gene flow of fauna and flora; and ensure the well-being of human populations (EMBRAPA, 2020).

The benefit of riparian forests for the protection of rivers depends on their size and length. It is difficult to determine the minimum riparian width necessary to fulfill the ecological, geomorphological, and hydrological functions of a riparian forest. This parameter may depend on several aspects: angle of the slopes, river altimetry, climate (precipitation, erosivity, drought), physiography of the terrain, type of soil, nature of the regolith, presence of rocks, and vegetation type and density (VALLE et al., 2013).

The fixed widths of the riparian thickets are not always extensive enough to ensure buffering through filtering or fixation and retention of nutrients, especially the phosphorus and nitrogen transported from farms (SPAROVEK et al., 2010; METZGER, 2010; SWEENEY; WBOLD, 2014). The soil water regime modulated by geomorphic features of plains and by fluvial hydrodynamics should also be analyzed (CURCIO et al., 2006), in addition to the structure of the forest, because forest heterogeneity also influences the buffering capacity of riparian forests (SOUZA et al., 2013).

In studies conducted in the Capivari river microbasins, in the state of Paraná, Brazil, Fritzsons and Mantovani (2015) found that mining and agricultural land use, combined with the lack of riparian forests, increased turbidity and the amount of coliform bacteria in surface waters (FRITZSONS et al., 2011). Despite ample evidence, the importance of riparian forests is still under discussion. According to Pavlak et al. (2009), land use, whether associated with the riparian forest in the drainage basin or not, also influences the water quality of a basin.

Therefore, the objective of this study was to verify whether land use, occupation, and conflicts with fluvial PPAs influence water quality. To reach this goal, we identified and quantified the typologies of areas of land use, conflicts with fluvial PPAs, and water quality parameters of the basin. The data we gathered constitute secondary products of the study and serve as a reference for an agricultural area that is part of the green belt and an important groundwater source of the Metropolitan area of Curitiba.

\section{MATERIALS AND METHODS}

\section{Area description}

The Ribeirão da Onça basin, with an area of $22.56 \mathrm{~km}^{2}$, belongs to the Capivari basin, which is located in the first Paranaense Plateau, a phytoecological region of the Mixed Ombrophilous Forest (MOF) of the Atlantic Forest biome. Ribeirão da Onça is northwest of the city of Colombo, in the Metropolitan area of Curitiba, Paraná, between the coordinates $25^{\circ} 15^{\prime} 00^{\prime \prime} \mathrm{S}$ e $25^{\circ} 17^{\prime} 30^{\prime \prime} \mathrm{S}$ and $49^{\circ} 09^{\prime} 00^{\prime \prime} \mathrm{W}$, and $49^{\circ} 13^{\prime} 00^{\prime \prime} \mathrm{W}$. According to the Köeppen climate classification, this area has a temperate oceanic climate $(\mathrm{Cfb})$, with the coldest month between +18 and $3^{\circ} \mathrm{C}$, regular precipitation in all months of the year, sporadic severe frosts, rare snowfall, and a general lack of dry season (MAACK, 1981). In the basin, the various land uses (mining, agriculture, forestry, pastures, and buildings) are installed up to the banks of the main river or in its marginal dikes. Consequently, natural vegetation is replaced or eradicated, and that negatively impacts water quality (FRITZSONS; MANTOVANI, 2015).

The geological substrate is complex and consists of the crystalline basement, the Açungui Group, and the Capiru formation. Bigarella and Salamuni (1958) subdivide this Meso-Proterozoic group into the Setuva, Capiru, and Votuverava formations. The Capiru formation consists of a set of successive layers of folded metasedimentary rocks (phyllites, metadolomites, and quartzites) all interspersed with dikes of Diabasio of the Late Cretaceous, of Valanginian stage. This area is in the southern part of a karst aquifer that developed over metadolomites. In this region, good quality alkaline-earth groundwater from this aquifer is exploited at low costs of adduction and treatment when compared to alternative capture methods in the surface springs of the Metropolitan area. However, these areas are also difficult to explore because they are naturally fragile. The complexity also increases due to faults, caves, and underground structures. Colombo and Almirante Tamandaré are municipalities that are partially located on karst features in the northern portion of the Metropolitan area of Curitiba. Over time, the soil may erode and collapse, and this has social and economic repercussions. This is because these municipalities significantly expanded in terms of population in recent years (NOGUEIRA FILHO, 2006), which may lead to conurbation processes.

\section{Water quality assessment and monitoring}

We selected six distinct sites in the drainage basin (Table 1) to monitor fluvial water quality. The collection of water samples commenced in February 2014 and ended in June 2016 throughout 33 field campaigns. All water samples were refrigerated after being collected and sent to the laboratory on the same day. The following factors were analyzed: turbidity, color, $\mathrm{pH}$, electrical conductivity (total dissolved solids), alkalinity, and nitrate and chloride concentrations. As recommended by SUDERHSA (1997), we employed a 0.6 electrical conductivity ratio to calculate soluble solids.

Daily precipitation data of the automatic station (Colombo Copel, code 02549090) were obtained from the Instituto das Águas do Paraná. The station is close to collection point 06 (Figure 1). The accumulated precipitation (in $\mathrm{mm}$ ) of ten days prior to the date of collection was accounted for to verify any residual effects

FLORESTA, Curitiba, PR, v. 51, n. 2, p. 283-292, abril/jun 2021.

Fritzsons, E. et.al.

ISSN eletrônico 1982-4688

DOI: $10.5380 /$ rf.v51 i2. 62957 
possibly triggered by the rain on water quality.

In possession of the analytical data, we verified significant differences in water quality between the collection points. The seasons (spring, summer, autumn, and winter) were also accounted for to verify possible changes in water quality. The $\mathrm{pH}$ was delogarithmized to be submitted to the analyzes.

\section{Land use and conflicts}

The sections of the microbasins were delimited based on points distributed in the drainage basin and along the rivers, tributaries of the Ribeirão da Onça basin and the Ribeirão da Onça river itself. This was done to facilitate the analyses of land use and conflicts with fluvial PPAs. The area of the basin was subdivided as follows: the first point was at the mouth of Ribeirão da Onça, which flows into the Capivari river (point 01), and we traced the drainage basin from the mouth. Water collection points were spatially distributed in the basin and along the tributaries of the river. From each collection point (mouths), the hydrographic microbasins (upstream of each point) were traced, so that each microbasin was part of the next microbasin. For example, point 01, which drains the largest area, is in the mouth of the Ribeirão da Onça basin and is downstream of point 02, which is in the Capivari floodplain. Point 02 is downstream of point 03, which in turn is downstream of point 04 . Points 05 and 06 drain isolated basins that join at point 04 (Figure 1).

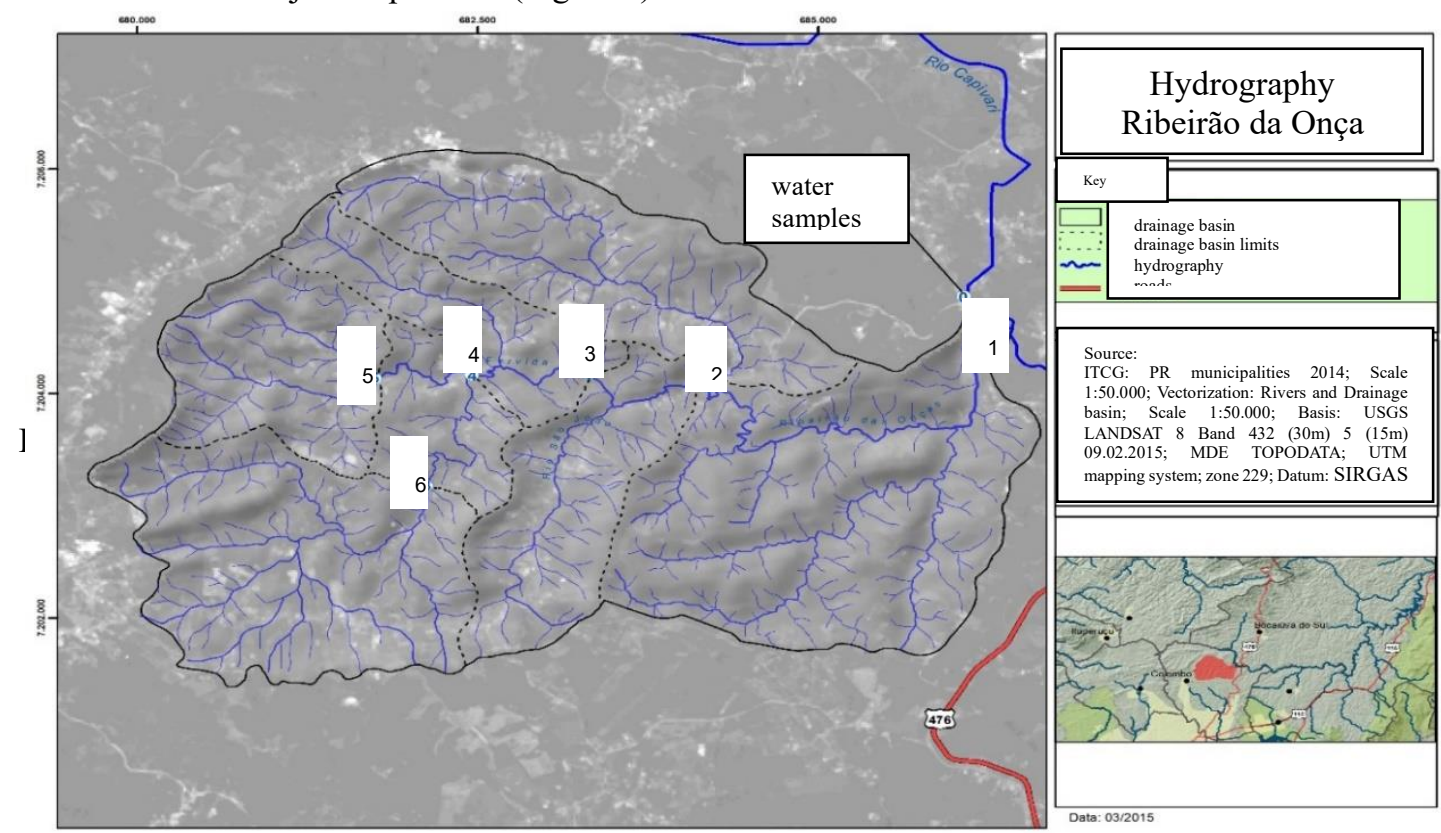

Figure 1. Location of water collection points in the Ribeirão da Onça basin.

Figura 1. Localização dos pontos de coleta de água na bacia de Ribeirão da Onça.

We produced the land use chart to obtain the conflict map with the fluvial PPAs. We obtained and interpreted the satellite image Landsat 8 of 03/2015 from the United States Geological Survey - USGS website. The images contained multispectral bands with a spatial resolution of $30 \mathrm{~m}$ and the panchromatic band with a spatial resolution of $15 \mathrm{~m}$. The Landsat 8 images were processed with geometric corrections and radiometric calibrations. The fusion of the multispectral bands with pixels of $30 \mathrm{~m}$ with the panchromatic Band $8(15 \mathrm{~m})$ was generated, obtaining an image, in true color, with a spatial resolution of $15 \mathrm{~m}$. The classification of the merged image was generated through the "iso cluster" method, unsupervised, with five classes (Buildings, Natural Forests, Forestry, Agriculture, Pastures, and Mining). Once this process was completed, the classified images were edited to correct visual interpretation errors. From the merged image, we were able to accurately vectorize hydrography and Hydrographic boundaries and delimit the drainage basin.

For the conflict map, the cartographic data were obtained from the Instituto de Terras Cartografia e Geociências do Paraná - ITCG website, at a scale of 1:50,000, with the drainage networks. According to the Brazilian Forest Code, Law 12.651 (BRASIL, 2012), the minimum required width of the riparian forest for the rivers of that basin is 5 meters on each side. The area of properties in the region is on average 5.5 ha and the municipality of Colombo applies a tax module to $10 \mathrm{ha}\left(100,000 \mathrm{~m}^{2}\right)$ areas. Thus, since most small rural properties in the area have 2 tax modules at most, the calculation of the width of the riparian forests for the permanent preservation areas is 5 meters on each bank of the river.

In this way, a 5-meter-wide buffer was generated for each side of the river. The area created by the buffer was crossed with the standard classification of use and land cover. The permanent preservation areas were broken

FLORESTA, Curitiba, PR, v. 51, n. 2, p. 283-292, abril/jun 2021

Fritzsons, E. et.al.

ISSN eletrônico 1982-4688

DOI: $10.5380 /$ rf.v51 i2. 62957 
down into the typologies present in the area. The areas where there should be forests, but they were not present, marked as conflicting with fluvial PPAs, were accounted for. With the data on the basin area, land use, and conflicts, we obtained the percentages of these parameters for each of the microbasins.

\section{Correlation between water quality parameters and rainfall}

The values of the water quality parameters, obtained in the 33 field campaigns, were analyzed, submitted to Pearson correlation analysis, and associated with the precipitation (sum) accumulated for ten days before the day the samples were gathered. The respective coefficients of determination were calculated to verify the adjustment. The degree of correlation by Pearson's coefficients was verified as proposed by Devore (2006): $r$ from 0.00 to 0.19 , very low correlation; $r$ from 0.20 to 0.39 , low correlation; $r$ from 0.40 to 0.69 , moderate correlation; $\mathrm{r}$ from 0.70 to 0.89 , high correlation; and $\mathrm{r}$ from 0.90 to 1.00 , very high correlation.

\section{Correlation between land use, conflicts with fluvial PPAs, and water quality}

Land use and occupation, conflicts with fluvial PPAs, and water quality parameters were statistically correlated. To this end, we calculated the average water quality parameters for each of the six water collection points of the basin (microbasins). These values were associated with the percentages of land use and the percentages of conflicts with fluvial PPAs in the microbasins, which were also converted into average values.

\section{RESULTS}

In the Ribeirão da Onça basin, there is a striking presence of natural ( $41 \%$ of the area) and planted forests ( $25 \%$ of the area). The reforestation was done with bracatinga (Mimosa scabrella), a species native to the region, eucalyptus (Eucalyptus sp.) and pinus (Pinus sp.). Agriculture (23\% of the area) is found in areas with a smoother topography and karstic substrates. The sheds, barns, residences, and roads are part of the typology called "buildings" ( $7.2 \%$ of the area). In the northern portion of the basin, there are metadolomite mines intended to produce agricultural neutralizers and lime production ( $0.9 \%$ of the area). There are few pastures in the area $(1.7 \%$ of the area) (Figure 2).

Approximately $50 \%$ of the total area of the basin conflicts with the fluvial PPAs, which means half of the basin does not have the fluvial PPA covered by riparian forests, not even the recommended 0 to 5 meters for each riverbank. However, there are differences in this distribution throughout the basin. On the eastern side, the proportion of conflicts is lower due to the higher percentage of use and forest occupation, planted or natural, as shown in Figure 2 (left). Agriculture is the typology that conflicts the most with PPAs (22.29\%), as seen in Figure 2 (right), followed by reforestation (16.59\%) and buildings (7.64\%). The conflict of pastures and mining areas with PPAs represent $1.91 \%$ and $0.64 \%$ of the territory respectively. Although their environmental impact is minimal, these activities have a visual effect on the landscape.

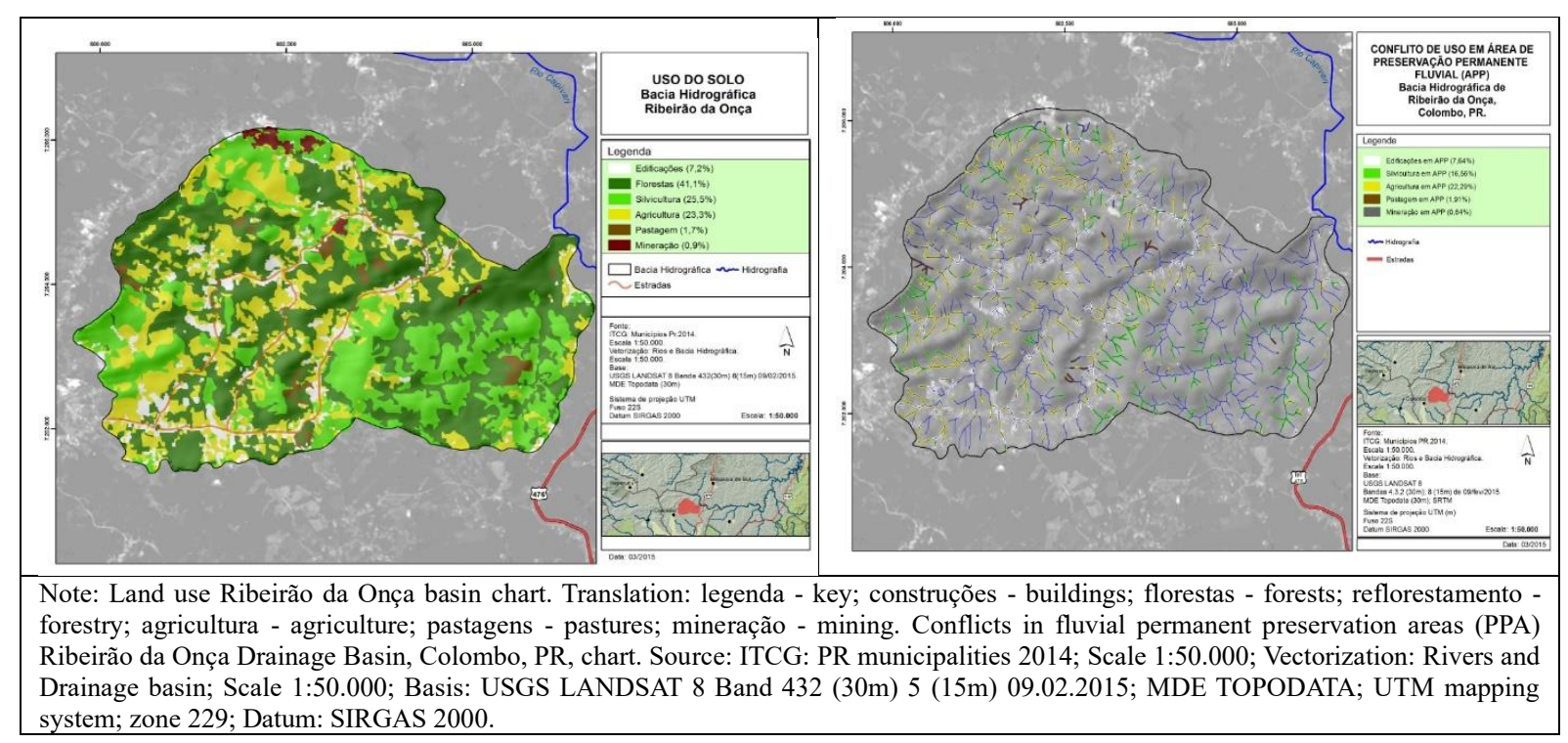

Figure 2. Chart of land use and cover on the left and chart of conflicts with fluvial PPA on the right.

Figura 2. Carta de uso e cobertura da terra a esquerda e carta de conflito de uso das APPs fluviais a direita.

The percentage breakdown of land use sectorized for each micro-basin and the percentage of conflicts with riparian PPAs are included in Table 1. Since natural forests are typical of riparian areas of the region, there is

FLORESTA, Curitiba, PR, v. 51, n. 2, p. 283-292, abril/jun 2021.

Fritzsons, E. et.al.

ISSN eletrônico 1982-4688 
no conflict in this category. In the last column, there is the sum of the typologies of conflicts with PPAs for each microbasin.

Table 1. Typologies of land use and conflicts with riparian forests, in percentages, for hydrographic microbasins. Tabela 1. Tipologias de uso da terra e de conflito de uso das florestas ciliares, em porcentagem de área, para as microbacias hidrográficas.

\begin{tabular}{|c|c|c|c|c|c|c|c|c|}
\hline Typologies & Microbasin & Buildings & Forestry & Natural Forests & Agriculture & Pastures & Mining & Sum \\
\hline \multirow{6}{*}{ 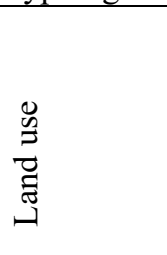 } & 1 & 7.64 & 16.53 & 38.81 & 22.29 & 1.91 & 0.64 & \\
\hline & 2 & 10.62 & 15.93 & 32.6 & 29.2 & 2.62 & 0.88 & \\
\hline & 3 & 12.9 & 12.9 & 31.87 & 32.26 & 0 & missing & \\
\hline & 4 & 11.86 & 10.17 & 8.4 & 30.51 & 1.69 & missing & \\
\hline & 5 & 10.53 & 10.53 & 41.37 & 26.32 & 5.26 & missing & \\
\hline & 6 & 11.43 & 11.43 & 41.76 & 30 & 2.86 & missing & \\
\hline \multirow{6}{*}{ 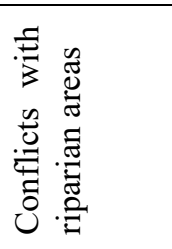 } & 1 & 9.39 & 20.52 & - & 29.73 & 1.73 & 1.17 & 62 \\
\hline & 2 & 12.25 & 23.63 & - & 33.48 & missing & missing & 70 \\
\hline & 3 & 5.13 & 7.69 & - & 19.41 & 1.59 & missing & 34 \\
\hline & 4 & 8.4 & 12.18 & - & 28.57 & 1.68 & missing & 51 \\
\hline & 5 & 9.89 & 17.26 & - & 31.48 & 1.31 & missing & 60 \\
\hline & 6 & 7.26 & 25.76 & - & 23.59 & 1.73 & 0.93 & 58 \\
\hline
\end{tabular}

In the statistical analysis, water quality and precipitation, apart from color, did not show normal distribution. Thus, the values were converted into the square root and to the logarithmic scale. After these procedures, the values were resubmitted to the normality assessment. Nevertheless, for all the parameters analyzed, the Curtose test was outside the range of -2 to +2 , indicating a lack of normality in the distribution. Given the lack of normality, we opted to apply the nonparametric Kruskal-Wallis test (Table 2). Differences, when existent, could be observed in the Box Plot (Box and Whiskers).

Table 2. The Kruskal-Wallis test was applied for water quality parameters between seasons and between collection points. The maximum, minimum, and mean values were calculated for the number of samples.

Tabela 2. Teste de Kruskal Wallis para os parâmetros de qualidade de água entre as estações do ano e entre pontos de coleta, e o número de amostras, os valores máximos, os mínimos e os médios.

\begin{tabular}{|c|c|c|c|c|c|c|c|c|}
\hline \multirow{2}{*}{ Parameters } & \multirow[b]{2}{*}{ 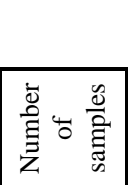 } & \multirow[b]{2}{*}{ 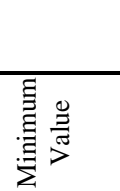 } & \multirow[b]{2}{*}{ 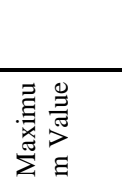 } & \multirow[b]{2}{*}{ 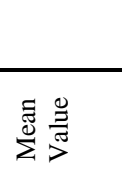 } & \multicolumn{2}{|c|}{$\begin{array}{l}\text { Comparison between } \\
\text { the seasons }\end{array}$} & \multicolumn{2}{|c|}{$\begin{array}{l}\text { Comparison between } \\
\text { collection points }\end{array}$} \\
\hline & & & & & $\stackrel{\overrightarrow{0}}{\oplus}$ & 采 & $\stackrel{\vec{w}}{\oplus}$ & $\begin{array}{l}\frac{0}{\pi} \\
\stackrel{1}{\pi} \\
2\end{array}$ \\
\hline Turbidity (NTU) & 183 & 0 & 650 & 36 & 5.800 & 0.1213 & 7.33 & 0.1970 \\
\hline Color $(\mathrm{Hu})$ & 185 & 0 & 400 & 14 & 21.13 & $0.0000^{*}$ & 7.40 & 0.1920 \\
\hline Conductivity $\left(\mu \mathrm{S} / \mathrm{cm}^{-1}\right)$ & 186 & 30 & 567 & 306 & 8.335 & $0.0039 *$ & 82.50 & $0.0000 *$ \\
\hline Nitrate $\left(\mathrm{mg} / \mathrm{L}^{-1}\right)$ & 108 & 0.01 & 1.64 & 0.98 & 14.68 & $0.0021 *$ & 27.357 & $0.0000^{*}$ \\
\hline Chloride concentration $\left(\mathrm{mg} / \mathrm{L}^{-1}\right)$ & 107 & 0.01 & 7.92 & 3.46 & 46.33 & $4.824 \mathrm{E}-10^{*}$ & 7.608 & 0.1791 \\
\hline Alkalinity $\left(\mathrm{CaCO} 3 \mathrm{mg} / \mathrm{L}^{-1}\right)$ & 175 & 9.3 & 244 & 136.8 & 17.19 & $0.0000 *$ & 61.35 & $5.85 \mathrm{E}^{-12^{*}}$ \\
\hline Dissolved solids $\left(\mathrm{mg} / \mathrm{L}^{-1}\right)$ & 175 & 20 & 571 & 215.9 & 13.92 & $0.0030^{*}$ & 97.21 & $0.0000^{*}$ \\
\hline $\begin{array}{l}\text { Hydrogenionic concentration } \\
\left(\mathrm{mol} / \mathrm{L}^{-1}\right)\end{array}$ & 186 & 3.24E-09 & $9.55 \mathrm{E}-07$ & $4.74 \mathrm{E}-08$ & 17.02 & $0.0001 *$ & 7.064 & 0.2158 \\
\hline Precipitation (mm) & 33 & 0 & 139 & 45 & 9.694 & $0.0213^{*}$ & - & - \\
\hline
\end{tabular}

Note: "Precipitation" is the sum of precipitation ten days before collection; "*” indicates the $P$ values lower than 0.05 , which indicate significant correlations at the $95.0 \%$ confidence level.

The only differences found between the seasons concerned turbidity. For the other parameters, the differences between the seasons were significant. The collection points, conductivity, nitrate concentration, alkalinity, and dissolved solids showed differences between them. Turbidity, color, and chloride and hydrogenionic concentration showed no differences between the points.

Based on the water quality parameters that showed significant differences, the Kruskal-Wallis test results were plotted into the "Box and Whiskers", as shown in Figure 3, including the precipitation in the seasons. This plot enables us to visualize the differences and similarities between individual seasons or collection points. The positive sign $(+)$ in the boxes refers to the mean and the center line is the median. Where the notches of the boxes do not overlap, there are differences between the groups. The numerical results of this interpretation for all parameters are included in Tables 3 and 4. 


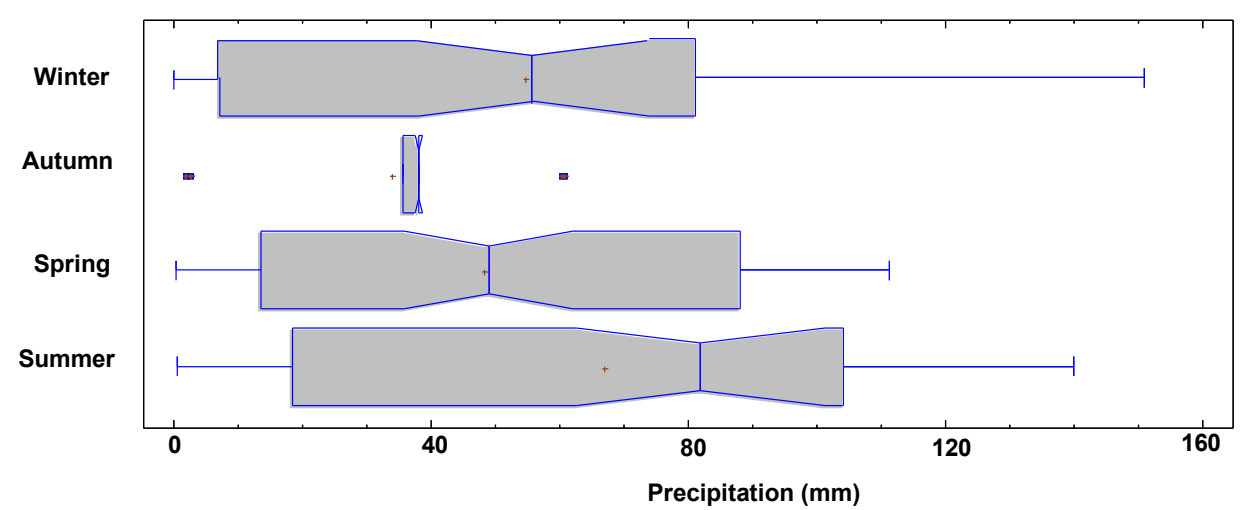

Figure 3. "Box and Whiskers" plot for precipitation in the seasons.

Figura 3. Gráfico "Caixa e Bigodes" para a precipitação nas estações do ano.

Table 3. Result based on the interpretation of the "Box and Whiskers" plot with the medians of the water quality parameters for the seasons.

Tabela 3. Resultado baseado na interpretação do gráfico "Caixa e Bigodes" com as medianas dos parâmetros de qualidade de água para as estações do ano.

\begin{tabular}{|c|c|c|c|c|c|c|c|}
\hline & Color $(\mathrm{Hu})$ & Chloride concentration $(\mathrm{mg} / \mathrm{L}-1)$ & $\begin{array}{l}\text { Alkalinity } \\
\text { (CaCO3 mg/L-1) }\end{array}$ & $\begin{array}{c}\text { Conductivity } \\
(\mu \mathrm{S} / \mathrm{cm}-1)\end{array}$ & $\begin{array}{l}\text { Precipitation } \\
(\mathrm{mm})\end{array}$ & $\begin{array}{l}\text { Nitrate } \\
\text { concentration } \\
\quad\left(\mathrm{mg} / \mathrm{L}^{-1}\right)\end{array}$ & $\begin{array}{l}\text { Dissolved } \\
\text { solids } \\
\left(\mathrm{mg} / \mathrm{L}^{-1}\right)\end{array}$ \\
\hline Spring & $3.2 \mathrm{ab}$ & (a) & $115 \mathrm{a}$ & $282 \mathrm{a}$ & $49 a$ & $0.98 \mathrm{~b}$ & $182 \mathrm{a}$ \\
\hline Summer & $7.5 \mathrm{~b}$ & $5.3 \mathrm{c}$ & $127 \mathrm{ab}$ & $303 \mathrm{a}$ & $82 b$ & $1.11 \mathrm{~b}$ & $205 b$ \\
\hline Autumn & $4.9 \mathrm{ab}$ & $3.4 \mathrm{~b}$ & $142 \mathrm{~b}$ & $304 \mathrm{a}$ & $38 \mathrm{a}$ & $0.89 \mathrm{ba}$ & $193 a b$ \\
\hline Winter & $1.1 \mathrm{a}$ & $2.8 \mathrm{~b}$ & $141 \mathrm{~b}$ & $320 \mathrm{~b}$ & $56 \mathrm{ab}$ & $1.13 \mathrm{a}$ & $208 b$ \\
\hline
\end{tabular}

Note: the same letters in the column do not denote significant differences between the parameters.

We selected the color parameter to illustrate the interpretation of Table 3. The median color in winter (a) is different from the median color in summer (b), although it does not differ from the color in autumn (ab) and the color in spring $(\mathrm{ab})$; the same occurs with the median color in winter (b), which does not differ from the color in autumn (ab) and the color in spring (ab).

Table 4. Value of medians for water quality parameters in collection points, based on the interpretation of the "Box and Whiskers" plot

Tabela 4. Valor das medianas para os parâmetros de qualidade de água, para os pontos de coleta, baseado na interpretação do gráfico "Caixa e Bigodes"

\begin{tabular}{ccccc}
\hline Collection points in the basin & $\begin{array}{c}\text { Conductivity } \\
\left(\mu \mathrm{S} / \mathrm{cm}^{-1}\right)\end{array}$ & $\begin{array}{c}\text { Nitrate concentration } \\
\left(\mathrm{mg} / \mathrm{L}^{-1}\right)\end{array}$ & $\begin{array}{c}\text { Dissolved solids } \\
\left(\mathrm{mg} / \mathrm{L}^{-1}\right)\end{array}$ & Alkalinity $\left(\mathrm{CaCO}_{3} \mathrm{mg} \mathrm{L}^{-1}\right)$ \\
\hline 1 & $198 \mathrm{a}$ & $0.48 \mathrm{a}$ & $121 \mathrm{a}$ & $87 \mathrm{a}$ \\
2 & $303 \mathrm{~b}$ & $1.03 \mathrm{~b}$ & $183 \mathrm{~b}$ & $139 \mathrm{~b}$ \\
3 & $354 \mathrm{c}$ & $1.18 \mathrm{~b}$ & $212 \mathrm{c}$ & $160 \mathrm{c}$ \\
4 & $333 \mathrm{bc}$ & $1.14 \mathrm{~b}$ & $202 \mathrm{bc}$ & $153 \mathrm{bc}$ \\
5 & $311 \mathrm{~b}$ & $1.1 \mathrm{~b}$ & $195 \mathrm{~b}$ & $141 \mathrm{~b}$ \\
\hline
\end{tabular}

Note: the same letters in the column do not denote significant differences between the parameters.

As for the collection points (Table 4), the mouth of the basin (point 1) presents the lowest values of conductivity (and dissolved solids), alkalinity, and nitrate concentration. As for the hydrogenionic and chloride concentration, since there were no differences in the values between the collection points, they were not included in this table. For conductivity, dissolved solids, and alkalinity, there were significant differences between the points (same letters), which is justified by the fact that the three parameters are related. Point 3 shows the largest values, compared to all points. For nitrate, the lowest concentration occurred at Point 1, the mouth of the basin.

The results of the correlation between the mean water quality parameters, conflicts with PPA, and land use are shown in Table 5. All water quality parameters of 78 samples were correlated with each other and with accumulated precipitation. Precipitation varied between the seasons and this parameter could be correlated,

FLORESTA, Curitiba, PR, v. 51, n. 2, p. 283-292, abril/jun 2021.

Fritzsons, E. et.al.

ISSN eletrônico 1982-4688

DOI: 10.5380/rf.v51 i2. 62957 
moderately and negatively, with alkalinity (-0.49), but not with turbidity or color.

Table 5. Pearson correlation between water quality parameters, conflicts with PPA, and land use.

Tabela 5. Correlação de Pearson entre parâmetros de qualidade de água, conflitos de uso das APPs e uso da terra.

\begin{tabular}{|c|c|c|c|c|c|c|c|c|c|c|c|c|c|c|c|c|}
\hline & & \multicolumn{7}{|c|}{ Water quality } & \multicolumn{3}{|c|}{ Land use } & \multicolumn{5}{|c|}{ Conflicts with PPA } \\
\hline \multirow{8}{*}{ 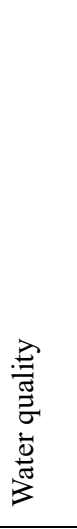 } & & 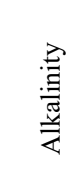 & 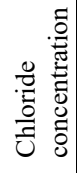 & 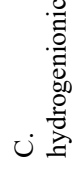 & 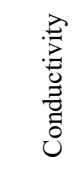 & $\frac{\overline{0}}{0}$ & 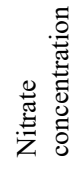 & 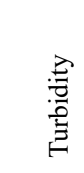 & 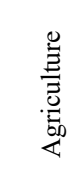 & 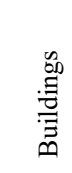 & 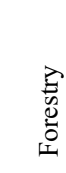 & 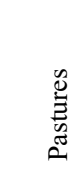 & 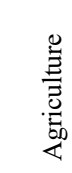 & 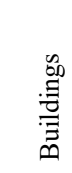 & 哭 & 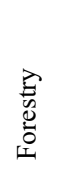 \\
\hline & Alkalinity & & & 0.84 & 0.98 & 0.87 & 0.81 & & & & & & 0.92 & 0.97 & & \\
\hline & $\begin{array}{l}\text { Chloride } \\
\text { concentration }\end{array}$ & & & & & & & & & & & 0.82 & & & & \\
\hline & $\begin{array}{l}\text { Hydrog. } \\
\text { conc. }\end{array}$ & 0.84 & & & & & 0.94 & & & & & & & & & \\
\hline & Conductivity & 0.98 & & & & & & & & & & & 0.88 & 0.94 & & \\
\hline & Color & 0.87 & & & & & & 0.91 & & & & & 0.95 & 0.89 & & \\
\hline & NO3 Nitrate & 0.81 & & 0.94 & & & & & & & & & & & & \\
\hline & Turbidity & & & & & 0.91 & & & & & & -0.82 & & & & \\
\hline & Agriculture & & & & & & & & & 0.97 & & & & 0.96 & & \\
\hline च & Buildings & & & & & & & & 0.97 & & & & & & & \\
\hline 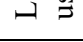 & Forestry & & & & & & & & & & & & & & & 0.83 \\
\hline & Pastures & & 0.82 & & & & & -0.82 & & & & & & & & \\
\hline & Agriculture & 0.92 & & & 0.88 & 0.95 & & & & & & & & 0.96 & & \\
\hline 岂 & Buildings & 0.97 & & & 0.94 & 0.89 & & & 0.96 & & & & 0.96 & & & \\
\hline ī & Mining & & & & & & & & & & & & & & & 0.90 \\
\hline & Forestry & & & & & & & & & & 0.83 & & & & 0.90 & \\
\hline
\end{tabular}

\section{DISCUSSION}

In $51 \%$ of the Ribeirão da Onça basin, there is compliance with the Brazilian Forest Code, Law No. 12,651/2012 (BRASIL, 2012). However, we found conflicts with the PPA legislation in $49 \%$ of the basin. Microbasin 2 (Table 1) has a strong imbalance with agriculture and microbasin 1 with forestry; these activities invade the riparian belt. Agriculture was the biggest source of conflicts with PPAs. Thus, to regenerate the riparian forests, the focus should be on adapting agricultural practices to preserve the range of PPA, especially in microbasins whose surrounding activities are the most imbalanced.

Studies show that wider riparian forests are more effective in terms of protection (SWEENEY; NEWBOLD, 2014). In this study, we used the 5-meter range standard for riparian forest on both riverbanks, which is the mandatory width according to the rules of the Brazilian Forest Code, Law No. 12.651/2012 (BRASIL, 2012) when applied to the area. However, the results could be different if we consider a width of riparian forests that offers more protection to water resources (LEITE et al., 2020). A wider area is also more favorable to biota because it enables the formation of niches, such as nesting and feeding areas, for all native species. Chase et al. (2016) state that relatively small increases in riparian forest cover may lead to statistically detectable and ecologically significant improvements in the health of rivers.

Sweeney and Newbold (2014) state that a 30-meter-wide riparian forest would be required to protect water quality and biota in rivers in basins smaller than $100 \mathrm{~km}^{2}$. This figure is suitable for our study since the Ribeirão da Onça basin is $26 \mathrm{~km}^{2}$. The previous Forest Code, established by Law No. 4,771/1965 (BRASIL, 1965), required 30-meterwide riparian forests for each of the banks in rivers up to 10 meters wide. Since this topic is still under debate, some authors consider other widths to be more suitable to protect the water quality of rivers (CURCIO et al. 2006; SPAROVEK et al., 2010; METZGER, 2010).

Regarding the relationship between land use and conflicts with PPA (Pearson correlation, Table 5), there was a strong and positive relationship $(\mathrm{r}=0.96)$ between the conflict of agriculture and buildings with fluvial PPAs. Thus, in basins where agricultural areas reached the riverbanks, buildings were also nearby. This is because the agriculture in this region is based on horticulture, which develops in flat or smooth wavy reliefs and next to rivers, invading the PPAs. The rural properties are small, and therefore, the buildings also occupy areas near the rivers (FRITZSONS et al., 2011). The buildings consist of houses, greenhouses, barns, and sheds. The areas of bare land and roads attached to these buildings were also accounted for in this typology. Animal husbandry is generally intended for self-consumption (FRITZSONS et al., 2011).

The agricultural use of basins goes along with the use of basins with buildings $(r=0.97)$. This reinforces this association of typologies of land use and occupation that occurs in the basin, as explained previously.

FLORESTA, Curitiba, PR, v. 51, n. 2, p. 283-292, abril/jun 2021.

Fritzsons, E. et.al.

ISSN eletrônico 1982-4688

DOI: $10.5380 /$ rf.v51 i2. 62957 
The conflict of buildings with PPAs is also strongly associated with alkalinity ( $\mathrm{r}=0.97)$, conductivity (and dissolved solids) $(\mathrm{r}=0.94)$, and color $(\mathrm{r}=0.89)$. The same occurs with water quality in basins where PPAs conflicted with agriculture (alkalinity, $\mathrm{r}=0.92$; conductivity, $\mathrm{r}=0.88$, and color, $\mathrm{r}=0.95$ ) (Table 5).

We found a strong correlation between forestry and mining $(\mathrm{r}=0.90)$, which means that in basins where mining is practiced, so is forestry. There was also a conflict between the PPAs and forestry ( $\mathrm{r}=0.83$ ). Forestry is practiced up to the banks of rivers, disregarding the width of river PPAs, as can be seen in microbasin 1 .

Water conductivity and alkalinity are strongly correlated $(\mathrm{r}=0.98)$ (Table 5). Conductivity represents the concentration of soluble solids, and in more alkaline waters the conductivity is also high. Electrical conductivity is a good indicator of the mineral concentration in water (TUNDISI; MATSUMURA, 2008).

The dissolved solids presented a mean value of $216 \mathrm{mg} / \mathrm{L}^{-1}$, with a minimum of $20 \mathrm{mg} / \mathrm{L}^{-1}$ and a maximum of $571 \mathrm{mg} / \mathrm{L}^{-1}$, whereas the water conductivity had a mean of $306 \mu \mathrm{s} / \mathrm{cm}^{-1}$, with a minimum of $30 \mu \mathrm{S} / \mathrm{cm}^{-1}$ and a maximum of $567 \mu \mathrm{S} \mathrm{cm}^{-1}$. The electrical conductivity for freshwater rivers ranges from 0 to $800 \mu \mathrm{S} / \mathrm{cm}^{-1}$. The conductivity found in our study is within the average range for rivers. In tropical areas, conductivity is related to the geochemical characteristics and climatic conditions of the region (periodicity and precipitation volume) (ESTEVES, 2011). Land use can directly modify the water composition and affect electrical conductivity. This can cause the electrical conductivity in rivers with the same source and different drains to vary (PAVLAK et al., 2009; ESTEVES, 2011). Even the conservation of vegetation in the basin has an influence on electrical conductivity values (MARMONTEL). In the basin studied, the different uses of the land and changes in the types of use of the PPAs modify the conductivity.

According to Esteves (2011), electrical conductivity changes with seasonality, being lower in the rainy period due to an increase in the ion dilution factor. Nevertheless, the release of effluents can raise the values of electrical conductivity regardless of seasonality. According to the methodology used in this work, precipitation, which was accounted for 10 days prior to the collection of the water sample, was not related to conductivity despite changing water dilution. The conductivity was significantly higher in the winter, the driest season (Table 3), although it remained consistent throughout the remaining seasons. The conductivity was lower in point 1 , where the drained area is larger and land use is more oriented to forestry (Table 1), whereas points 3 and 4 presented the highest values for conductivity. A more detailed study on land use and occupation and conflicts with riparian PPAs could clarify the differences in conductivity between the collection points.

The alkalinity of the water was lower in the samples collected in spring compared to the other seasons. This may be associated with the return of rains under a lower potential evapotranspiration, which results in greater water availability. The natural alkalinity of the water comes from the dissolution of rocks and the reaction of $\mathrm{CO}_{2}$ with water. Surface waters rarely exceed $500 \mathrm{mg} / \mathrm{L}^{-1}$ of $\mathrm{CaCO}_{3}$ (BITTENCOURT; HINDI, 2000) and the mean alkalinity found in the water of the basin was $137 \mathrm{mg} / \mathrm{L}^{-1}$, with a maximum value of $244 \mathrm{mg} / \mathrm{L}^{-1}$ (Table 4 ).

Several studies relate water turbidity to precipitation (FRITZSONS et al., 2011; MENDES; FERREIRA, 2014), but this is not verifiable in our study. The scale of the study might be behind this since turbidity may vary between specific points. In the mouth of the microbasins, where the water collection points are, compensation for the entry of less turbid water from the tributary drainage channels could be accounted for. There was a strong relationship of apparent color in the basins whose PPAs conflicted with agriculture and buildings ( $\mathrm{r}=0.95$ and $\mathrm{r}=0.89$, respectively). The apparent color is produced by the drainage of areas with red clay soil that is suspended in the water and changes its color in times of flood. Although planted forests conflict with PPAs by occupying the areas of riparian forests, lessens the apparent color of the surface waters due to a smaller area of exposure to soil.

The color intensity of natural waters varies between 0 and $200 \mathrm{uH}$. Higher values represent waters with a high concentration of dissolved organic matter. Coloration below 10 units is almost unnoticeable. In Brazil, pre-treated water for distribution in urban systems has values of up to 75 color units (CONAMA Resolution no. 357, 2005). The mean color value obtained in our study was $14 \mathrm{uH}$, and the maximum value, $400 \mathrm{uH}$. Levels increased in samples gathered during the summer and decreasing in samples gathered in winter and spring. There were no differences in relation to color between collection points.

There was a very strong and positive correlation between mean color and turbidity $(\mathrm{r}=0.91)$ and a strong correlation between mean color and alkalinity ( $\mathrm{r}=0.87$ ) (Table 5). As for turbidity, the average value found was $36 \mathrm{NTU}$, ranging from zero to $650 \mathrm{NTU}$, but there were no differences between collection points nor between seasons. There was a strong and negative correlation between turbidity and conflict of pastures with PPAs $(\mathrm{r}=-0.82)$, thus in the basins where pastures replaced the native riparian forest, turbidity was lower. Fernandes et al. (2011) claim that well-managed pastures protect the soil and do not increase the amount of total solids in the water.

Nitrate concentration showed a strong correlation with alkalinity $(r=0.81)$. The nitrate concentration in rivers may be proportional to the drained agricultural area and the differences found in surface water contents may occur due to the influence of groundwater flow and riparian cover (CONNOLLY et al., 2015). High nitrate concentrations can also occur in contaminated domestic sewers, where ammonia and nitrite tend to appear in greater quantities (SUDERHSA, 1997). The nitrate concentration found in this study had a mean value of $0.98 \mathrm{mg} / \mathrm{L}^{-1}$ and a maximum value of 1.64 $\mathrm{mg} / \mathrm{L}^{-1}$. Since water becomes unsuitable for human consumption only when nitrate concentration is over $10 \mathrm{mg} / \mathrm{L}^{-1}$, the value we found is extremely low. In the area of the basin, horticulturists and some agricultural workers reside on-site. The total nitrogen values found in the samples were minimal and are within Class 1 standards (CONAMA resolution $357,2005)$ regarding the waters destined for supply. The nitrate concentration levels changed throughout the seasons,

FLORESTA, Curitiba, PR, v. 51, n. 2, p. 283-292, abril/jun 2021

Fritzsons, E. et.al.

ISSN eletrônico 1982-4688

DOI: $10.5380 /$ rf.v51 i2. 62957 
being lower in autumn and winter, and in point 1, which stood out from the other points. The higher flow at this point might have contributed to these changes.

Nitrate and chloride ions are not adsorbed by the components of the soil fractions. Therefore, they move easily in the soil solution and can be absorbed by the roots and translocated to the leaves, where they accumulate by transpiration or are leached to underground springs (JADOSKI et al., 2010). According to Ordinance No. 2,914 from December 12, 2011 (BRASIL, 2011) of the Ministry of Health, the maximum permissible chloride concentration in supply water is $250 \mathrm{mg} / \mathrm{L}^{-1}$. Levels above allowable can constitute health risks. The mean value found was $3.5 \mathrm{mg} / \mathrm{L}^{-1}$ and the maximum value of $7.9 \mathrm{mg} / \mathrm{L}^{-1}$ still low, chloride levels showed a positive correlation with the conflict of pastures with PPAs $(\mathrm{r}=0.82)$. We recommend that future studies investigate this relation further.

As for the hydrogenonic concentration, there was a strong correlation between alkalinity $(\mathrm{r}=0.84)$ and nitrate concentration $(\mathrm{r}=0.94)$. The hydrogenionic concentration did not change significantly between the seasons or collection points. The mean $\mathrm{pH}$ value was 7.79 , with the highest being 8.49 and the lowest being 6.02 . The $\mathrm{pH}$ affects the metabolism of several aquatic species. Resolution CONAMA 357 (2005) establishes that the pH of bodies of fresh water should be between 6 and 9 to protect aquatic life.

The sampling points differ from each other regarding the drainage area. Since point 1 drains the entire Ribeirão da Onça basin $(22.56 \mathrm{~km})^{2}$, it is the point with the largest volume of water and higher dilution capacity. In this study, we did not measure flow, thus we suggest future studies do so. To this end, in addition to evapotranspiration, the water consumed for irrigation of vegetables should be considered.

\section{CONCLUSIONS}

- In the Ribeirão da Onça basin, located in Colombo, Paraná, $41 \%$ of the area corresponded to natural forests, $25 \%$ to planted forests, $23 \%$ to horticulture, $7.2 \%$ to buildings, $0.9 \%$ to mining, and $1.7 \%$ to pastures.

- In $51 \%$ of the basin, the occupation complied with the legislation regarding the fluvial permanent preservation areas (PPA). In 49\%, the uses conflicted with riparian forests;

- The fluvial PPAs that conflicted with pasture, agriculture, and mining were strongly correlated with water quality parameters (alkalinity, chloride concentration, conductivity, color, and turbidity). No water quality parameter was associated with land use in the basin, which proves the effect of riparian areas on surface water quality;

- The agricultural land use was related to the fluvial conflict of buildings and agriculture with PPAs. This owes to the spatial distribution pattern of the rural area of the region, which is made up of small rural properties next to farms that reach the banks of the waters and invade fluvial PPAs;

- Alkalinity, chloride concentration, conductivity, color, and turbidity were the water quality parameters that effectively changed for all conflicts with fluvial PPAs;

- The conflicts of agriculture and buildings with fluvial PPAs are strongly associated with higher water alkalinity, as well as higher conductivity, higher apparent color value, higher turbidity and higher chloride concentration;

- Data on color and chloride concentration gathered during the summer had higher indices. In the spring, the alkalinity was lower because the waters are more acidic in this season;

- Alkalinity showed moderate and negative correlation with precipitation when all samples collected in the basin were considered;

- Turbidity did not change according to collection points, seasons, nor precipitation, which shows the need for further studies to understand these relationships;

- At the mouth of the basin, the conductivity, alkalinity, and dissolved solids values were lower.

\section{REFERENCES}

BIGARELLA, J.J.; SALAMUNI, R. Contribuição a geologia da região sul da Série Açungui (estado do Paraná). Bol. Paulista de Geografia. São Paulo, 29:3-19, 1958.

BITTENCOURT, A.V. L.; HINDI, E.C. Tópicos de hidroquímica. In: III CURSO SUDAMERICANO SOBRE EVALUCIÓN Y VULNERABILIDAD DE ACUÍFEROS. Asunción, Itaipu binacional, OEA, 2000.

BRASIL. Lei n ${ }^{\circ} 12.651$, de 25 de maio de 2012. Dispõe sobre a proteção da vegetação nativa; altera as Leis nos 6.938, de 31 de agosto de 1981, 9.393, de 19 de dezembro de 1996, e 11.428, de 22 de dezembro de 2006; revoga as Leis nos 4.771, de 15 de setembro de 1965, e 7.754, de 14 de abril de 1989, e a Medida Provisória no 2.166-67, de 24 de agosto de 2001; e dá outras providências. Diário Oficial da União, Brasília, DF, vinte cinco de maio de 2012. Disponível em: <http://www.planalto.gov.br/ccivil_03/_Ato2011-2014/2012/Lei/L12651.htm>. Acesso em: 300920.

BRASIL. Ministério da Saúde. Portaria n. ${ }^{\circ}$ 2.914, de 12 de dezembro de 2011. Disponível em : https://bvsms.saude.gov.br/bvs/saudelegis/gm/2011/prt2914_12 12 2011.html\#: :text=Disp\%C3\%B5e\%20sobre\%20 os $\% 20$ procedimentos $\% 20 \mathrm{de}, \mathrm{e} \% 20 \mathrm{seu} \% 20 \mathrm{padr} \% \mathrm{C} 3 \% \mathrm{~A} 3 \mathrm{o} \% 20 \mathrm{de} \% 20$ potabilidade.\&text $=2 \% \mathrm{C} 2 \% \mathrm{~B} 0 \% 20$ Esta $\% 20 \mathrm{Port}$ aria\%20se,alternativa\%20de\%20abastecimento\%20de\%20\%C3\%A1gua. Acesso: 011020.

CHASE, J.; BENOY, G.; HANN, S.; CULP, J. Small differences in riparian vegetation significantly reduce land use

FLORESTA, Curitiba, PR, v. 51, n. 2, p. 283-292, abril/jun 2021.

Fritzsons, E. et.al.

ISSN eletrônico 1982-4688

DOI: $10.5380 /$ rf.v51 i2. 62957 
impacts on stream flow and water quality in small agricultural watersheds. J. Soil Water Conserv, 71 (3), pp. 194-205, 2016.

CONNOLLY, M. M.; PEARSON, R. G.; LOONG, D.; MAUGHAN, M.; BRODIE, J. Water quality variation along streams with similar agricultural development but contrasting riparian vegetation. Agriculture Ecosystems \& Environment. Amsterdam, v. 213, p. 11-20, 2015.

CURCIO, G. R.; UHLMANN, A.; SEVEBNANI, L. A geopedologia e sua influência sobre espécies arbóreas de florestas fluviais. Colombo: Embrapa Florestas, 31 p. (Embrapa Florestas. Documentos, 135). 2006.

EMBRAPA. Código Florestal: Adequação ambiental da paisagem rural. Disponível em https://www.embrapa.br/codigoflorestal/entenda-o-codigo-florestal/area-de-preservacao-permanente. Data da disponibilidade: 10/01/2020

ESTEVES, F. Fundamentos de limnologia. 3. ed. Rio de Janeiro: Interciência, 826 p., 2011.

FERNANDES, M. M., CEDDIA, M. B., RAMOS, G. M., GASPAR, A., MOURA, M. R. Influência do uso do solo na qualidade de água da microbacia Glória, Macaé - RJ. Engenharia Ambiental, 8(2): 105-116, 2011.

FRITZSONS, E.; MANTOVANI, L. E.; ROSA FILHO, E. Groundwater nitrogen pollution by conventional horticultural production in karst areas of the state of Paraná, Brazil. In: BIBLIO, C.; HENSEL, O.; SELBACH, J. F. (Org.). Sustainable water management in the tropics and subtropics - and case studies in Brazil. Jaguarão: Fundação Universidade Federal do Pampa, v. 1, p. 409-422, 2011.

FRITZSONS, E; MANTOVANI, L.E. Qualidade da água e o uso e cobertura da terra da bacia de Ribeirão da Onça, Colombo, Colombo: Embrapa Florestas, 2015. 26 p. - (Documentos / Embrapa Florestas, ISSN 1980-3958; 281).

JADOSKI, S.; ROMÃO SAITO, L.; PRADO, C. DO, LOPES, E.C.; RESENDE SALES, L. L.S. " Características da lixiviação de nitrato em áreas de cultivo intensivo." Applied Research \& Agrotechnology [online], 3.1 (2010): n. pag. Rede. 1 de outubro de 2020. Disponível em: https://revistas.unicentro.br/index.php/repaa/article/view/1008/1077 010120; data da disponibilidade: 011020.

LEITE, L. H. et al. Áreas de preservação permanente na serra da Mantiqueira: perspectivas de regularização ao longo dos cursos de água. Rev. Ambiente e Água, Taubaté, v. 15, n. 1, e2422, 2020. Disponível em $<$ http://www.scielo.br/scielo.php?script=sci arttext\&pid=S1980-993X2020000100302\&lng=en\&nrm=iso $>$. acesso em 28 de julho de 2020. Epub 10 de fevereiro de 2020. http://dx.doi.org/10.4136/ambi-agua.2422.

MAACK, R. Geografia física do Estado do Paraná. Rio de Janeiro: J. Olympio, 1981.

MARMONTEL, C. V. F.; RODRIGUES, V. A. Parâmetros Indicativos para Qualidade da Água em Nascentes com Diferentes Coberturas de Terra e Conservação da Vegetação Ciliar. Floresta e Ambiente, 22(2):171-181, 2015. http://dx.doi.org/10.1590/2179-8087.082014.

MENDES, L. da S.; FERREIRA, I. M. Influência da sazonalidade na qualidade da água bruta no município de ItuiutabaMG. Revista Brasileira de Geografia Médica e da Saúde, HYGEIA, ISSN: 1980-1726. Dez, 2014.

METZGER, J. P. O Código Florestal tem base científica? Natureza \& Conservação, Curitiba, v. 8, n. 1, p. 92-99, 2010.

PAVLAK, A. F.; DURREWALD, M. S.; FEY, A. R.; CONTI, C. Avaliação das características físico químicas da água do córrego Arroio Fundo em função de cinco usos do solo. Synergismus scyentifica. Pato Branco, 04 (1), 2009.

RESOLUÇÃO CONAMA. N. 357, DE 17 DE MARÇO DE 2005. Publicada no DOU nº 053, de 18/03/2005, págs. 5863.

SOUZA, A. L. T., D. G. FONSECA, R. A. LIBÓRIO \& M. O. TANAKA. Influence of riparian vegetation and forest structure on the water quality of rural low-order streams in SE Brazil. Forest Ecology and Management 298: 12-18, 2013.

SPAROVEK G, BERNDES G, KLUG ILF, BARRETTO AGOP. Brazilian agriculture and environmental legislation: status and future challenges. Environmental Science \& Technology, Newcastle, 44(16): 6046-6053, 2010.

SUDERHSA. Qualidade das Águas Interiores do Estado do Paraná (1987- 1995). Curitiba, 1997

SWEENEY, B. M. W.; NEWBOLD, J. D. Streamside Forest Buffer Width Needed to Protect Stream Water Quality, Habitat, and Organisms: A Literature Review. JAWRA. Journal of the American Water Resources Association. Middleburg, n. 3, p. 560-584, 2014.

VALLE, I. C; BUSS, D. F; BAPTISTA, D. F. The influence of connectivity in forest patches, and riparian vegetation width on stream macroinvertebrate fauna. Braz. J. Biol., São Carlos, v. 73, n. 2, p. 231-238, May 2013.

FLORESTA, Curitiba, PR, v. 51, n. 2, p. 283-292, abril/jun 2021.

Fritzsons, E. et.al.

ISSN eletrônico 1982-4688

DOI: $10.5380 /$ rf.v51 i2. 62957 